\title{
HUBUNGAN LAMA PEMAKAIAN KB SUNTIK 3 BULAN DEPO MEDROSIK PROGESTERON ASETAT (DMPA) DENGAN PENINGKATAN BERAT BADAN
}

\author{
Analia Kunang $^{1^{*}}$, Yeti Septiasari ${ }^{2}$, Dwi Meinanda ${ }^{3}$ \\ 1 Prodi DIII Kebidanan, Fakultas Kesehatan, Universitas Muhammadiyah Pringsewu \\ 2 Prodi S1 Keperawatan, Fakultas Kesehatan, Universitas Muhammadiyah Pringsewu \\ 3 Puskesmas Sukamara, Kec. Bulok, Kab. Tanggamus
}

Email :

12analiakunang@gmail.com, ${ }^{2}$ yetiseptiasari85@gmail.com, ${ }^{3}$ dewimeinandaaa@gmail.com

\begin{abstract}
ABSTRAK
Latar Belakang : Kontrasepsi suntik Depo Medroksi Progesteron Asetat (DMPA) merupakan jenis kontrasepsi keluarga berencana yang banyak digunakan dan efektif dalam menekan jumlah angka kelahiran. Salah satu dampak penggunaan KB suntik DMPA adalah peningkatan berat badan. Penelitian ini bertujuan untuk mengetahui hubungan lama pemakaian KB suntik 3 bulan Depo Medrosik Progesteron Asetat (DMPA) dengan peningkatan berat badan di BPM Selva Tiara Kec Bulok Kab. Tanggamus. Metode : penelitian ini menggunakan pendekatan Cross Sectional. Populasi dalam penelitian ini adalah seluruh lbu yang memakai KB suntik 3 bulan DMPA di BPM Selva sebanyak 42 responden. Tekhnik sampling yang digunakan adalah Total sampling. Hasil Penelitian : analisa univariat diketahui responden dengan lama penggunaan $>4$ Tahun yaitu sebanyak 17 responden $(40,5 \%)$ dan responden yang mengalami peningkatan badan yaitu sebanyak 31 responden (73,8\%). Ada hubungan antara lama pemakaian KB suntik 3 bulan Depo Medrosik Progesteron Asetat (DMPA) dengan peningkatan berat badan di BPM Selva Tiara Kec Bulok Kab. Tanggamus Tahun 2019 dengan p-value sebesar 0.011. Bagi pengguna kontrasepsi suntik DMPA untuk dapat melakukan pola hidup sehat seperti mengkonsumsi makanan sehat dan berolahraga sebagai upaya pencegahan peningkatan berat badan akibat efek samping kontrasepsi hormonal DMPA
\end{abstract}

Kata Kunci : KB Suntik. Peningkatan berat badan

\section{PENDAHULUAN}

Indonesia merupakan salah satu Negara yang berkembang dengan jumlah pertumbuhan penduduk yang tinggi. World Population data sheet 2013 menyatakan bahwa Indonesia merupakan Negara ke-5 di dunia dengan jumlah penduduk terbanyak yaitu 249 juta. Jumlah penduduk Indonesia tahun 2025 di perkirakan mencapai 237,7 juta jiwa atau mengalami kenaikan 57,9 juta jiwa dari perkiraan penduduk tahun 2000 sebanyak 205,8 pada tahun 2025 angka harapan hidup penduduk *Corresponding Author :

Analia Kunang Program Studi D-III Kebidanan, Fakultas Kesehatan Universitas Muhammadiyah Pringsewu Email : naliakunang@gmail.com
Indonesia juga akan mengalami peningkatan menjadi 73,2 tahun dari 69 tahun, sedang pada sensus pada tahun 1990 terdapat 180 juta jiwa (Irianto, 2014 dalam karya ilmiah Nursaidah, 2018).

Angka kematian ibu (AKI) pada tahun 2013 di indonesia mencapai 30,3 yang disebabkan perdarahan saat melahirkan. Begitu pula angka kematian ibu berdasarkan laporan SDKI tahun 2012 yaitu sebesar 359 per 100.000 kelahiran hidup (dengan target 102 per 10.000 kelahiran hidup) (Profil Kesehatan Indonesia tahun 
2013). Kasus kelahiran yang ada di provinsi Lampung tahun 2016 terbesar disebabkan oleh perdarahan saat melahirkan yaitu sebesar 45 kasus (Profil Kesehatan Provinsi Lampung, 2016).

Oleh karena itu sejalan dengan peraturan pemerintah Republik Indonesia no 87 tahun 2014 tentang perkembangan kependudukan dan pembangunan keluarga merupakan salah satu strategi untuk mengurangi kematian ibu Khususnya ibu dengan kondisi 4T: 1. Terlalu muda melahirkan (dibawah usia 20 tahun), 2. Terlalu tua melahirkan (diatas usia 35 tahun), 3. Terlalu sering melahirkan, 4.Terlalu dekat jarak melahirkan (Profil Kesehatan Indonesia, 2013). Maka dari itu pemerintah Indonesia melalui Badan Kependudukan dan Keluarga Berencana Nasional (BKKBN) akan melakukan penekanan jumlah angka kelahiran dengan pengelolaan dan pelaksanaan program Keluarga Berencana (KB) (BKKBN, 2016).

Menurut World Population Data Sheet 2013 Indonesia merupakan negara ke 5 didunia dengan estimasi jumlah penduduk terbanyak, yaitu 249 juta. Diatara Negara ASEAN, Indonesia tahun 2013, Indonesia dengan luar wilayah terbesar tetap menjadi Negara dengan penduduk tebanyak, jauh diatas 9 negara anggota lain. Dengan angka Fasilitas atau Total Fertility ( TFR) 2,6 Indonesia masih berada diatas rata-rata TFR Negara ASEAN, yaitu 2,4. Pusat data dan informasi, Kementrian Kesehatan RI, mengestimasi jumlah penduduk Indonesia tahun 2013 sejumlah 248 juta orang. Badan Pusat Statistik (BPS) mencatat bahwa pada tahun 2013, sebanyak 28,55 juta $(11,47 \%)$ penduduk Indonesia merupakan penduduk miskin (InfoDATIN, 2014).

Data Badan Kependudukan dan Keluarga Berencana Nasional (BKKBN) menunjukan bahwa pada tahun 2013 ada 8.500.247 PUS (Pasangan Usia Subur) yang merupakan peserta KB baru, dan Hampir Separuh nya $(48,56 \%)$ menggunakan kontrasepsi suntik. Menurut hasil laporan riset kesehatan dasar (Riskesdas) tahun 2013, menunjukan proporsi penggunaan KB di Indonesia pada tahun Riskesdas 2010 (55,8\%) dan Riskesdas 2013 (59,7\%).Penggunaan KB tahun 2013 menurut Provinsi bervariasi, secara umum terjadi peningkatan dalam priode 3 tahun.

Berdasarkan hasil capaian KB baru per Kabupaten/Kota terlihat bahwa penggunaan KB tertinggi ada di kabupaten Lampung Tengah (25,84\%), Metro (23,91\%), Lampung Barat (21,41\%). Sedangkan akseptor KB di daerah Tanggamus hanya sebesar (15,3\%). Dan pada tahun 2016 penggunaan alat kontrasepsi tebanyak adalah penggunaan KB Suntik yaitu sebesar (50,07\%) (Profil Kesehatan prov.Lampung, 2016).

Berdasarkan hasil survey pendahuluan yang ada di BPM Selva Tiara Kecamatan Bulok Kabupaten Tanggamus diperoleh data akaseptor kontrasepsi suntik pada bulan April 2018- Maret 2019 sebanyak 152 akseptor KB suntik DMPA. Sedangkan data yang diperoleh dari BPM Susanti Gusnia dari bulan April 2018 - Mare 2019 sebanyak 54 akseptor KB suntik DMPA.

Penelitian yang dilakukan oleh Pratiwi dkk (2014) di Puskesmas Lapai Kota Padang menunjukan bahwa dari 40 akseptor KB suntik DMPA 23 akseptor mengalami peningkatan berat badan setelah penggunaan KB suntik DMPA. Karakteristik akseptor diketahui umur 41-45 tahun dengan jumlah anak 2 berpotensi sangat besar untuk mengalami peningkatan BB. Hasil penelitian menunjukan bahwa sebelum menggunkan KB suntik DMPA berat badan ibu $54,40 \mathrm{~kg}$ setelah penggunaan $\mathrm{Kb}$ suntik DMPA meningkat menjadi $58,10 \mathrm{~kg}$. jadi akseptor mengalami penigkatan $\mathrm{BB}$ setalah pemakaian $\mathrm{KB}$

\section{*Corresponding Author :}

Analia Kunang

Program Studi D-III Kebidanan, Fakultas Kesehatan

Universitas Muhammadiyah Pringsewu

Email : naliakunang@gmail.com 
suntik DMPA, yaitu sebesar $57,5 \%$ (Pratiwi, 2014).

Sejala dengan penelitian yang dilakukan oleh Pratiwi, Syahredi \& Erkadius (2014) yang melakukan penelitian dengan judul hubungan antara penggunaan kontrasepsi hormonal suntik DMPA dengan peningkatan berat badan di Puskesmas Lapai Kota Padang. Hasil penelitian ini menunjukan bahwa ada hubungan antara penggunaan kontrasepsi hormonal dengan peningkatan berat badan. Penelitian lain yang dilakukan Suli (2018) di BPS Istri Utami Sleman menunjukan ada hubungan antara pemakaian kontrasepsi hormoanl dengan dengan kenaikan berat badan dengan kenaikan rata-rata $1,0-2,9 \mathrm{~kg}$, yaitu sebanyak 27 responden $(73,0 \%)$, dengan BB sebelum 56,39 $\mathrm{kg}$ dan setelah pemakaian KB suntik DMPA 58,92\%.

Berdasarkan hal tersebut maka penulis tertarik untuk mengambil kasus "Hubungan lama pemakaian KB suntik 3 bulan Depo Medrosik Progesteron Asetat (DMPA) dengan peningkatan berat badan di BPM Selva Tiara Kec Bulok Kab. Tanggamus".

\section{METODE}

Dalam penelitian ini penulis menggunakan metode cross-secctional, yaitu peneliti yang coba menggali bagaimana dan mengapa fenomena kesehatan itu terjadi untuk mengetahui apakah ada hubungan lama pemakaian KB suntik 3 bulan Depo Medrosik Progesteron Asetat (DMPA) dengan peningkatan berat badan di BPM Selva Tiara Kec Bulok Kab. Tanggamus (Notoatmodjo,2010)

\section{HASIL DAN PEMBAHASAN}

Hasil Analisa Univariat

Tabel 4.1 Distribusi frekuensi responden berdasarkan usia di BPM Selva Tiara Kec. Bulok Kab. Tanggamus Tahun 2019

\begin{tabular}{ccc}
\hline Usia Responden (Tahun) & Jumlah & Persentase \\
\hline $22-35$ & 30 & 71,4 \\
$34-45$ & 10 & 23,8 \\
$46-55$ & 2 & 4,8 \\
\hline Jumlah & 42 & 100 \\
\hline
\end{tabular}

Berdasarkan tabel 4.1 diketahui bahwa responden berusia 22-35 tahun sebanyak 30 responden $(71,4 \%)$, responden dengan usia 34-45 tahun sebanyak 10 responden $(23,8 \%)$ dan responden dengan usia 46-55 tahun sebanyak 2 responden (4,8\%).

Tabel 4.2 Distribusi frekuensi responden berdasarkan jenis kelamin di BPM Selva Tiara Kec. Bulok Kab. Tanggamus Tahun 2019

\begin{tabular}{ccc}
\hline Jenis Kelamin & Jumlah & Persentase \\
\hline Perempuan & 42 & 100 \\
Laki-laki & - & - \\
\hline Jumlah & 42 & 100 \\
\hline
\end{tabular}

Berdasarkan tabel 4.2 diketahui jenis kelamin seluruh responden dalam penelitian ini adalah perempuan yaitu sebanyak 42 responden (100\%).

Tabel 4.3 Distribusi frekuensi responden berdasarkan pendidikan di BPM Selva Tiara Kec. Bulok Kab. Tanggamus Tahun 2019

\begin{tabular}{ccc}
\hline Pendidikan & Jumlah & Persentase \\
\hline SD & 1 & 2,4 \\
SMP & 8 & 19,0 \\
SMA & 29 & 69,0 \\
Perguruan Tinggi & 4 & 9,5 \\
\hline Jumlah & 42 & 100 \\
\hline
\end{tabular}

Berdasarkan tabel 4.3 diketahui bahwa responden dengan pendidikan SD sebanyak 1 responden (2,4\%), responden dengan pendidikan SMP sebanyak 8 responden $(19,0 \%)$, responden dengan pendidikan SMA sebanyak 29 responden $(69,0 \%)$ dan responden dengan pendikan perguruan tinggi sebanyak 4 responden $(9,5 \%)$.

Tabel 4.4 Distribusi frekuensi responden berdasarkan pekerjaan di BPM Selva Tiara Kec. Bulok Kab. Tanggamus Tahun 2019

\author{
*Corresponding Author : \\ Analia Kunang \\ Program Studi D-III Kebidanan, Fakultas Kesehatan \\ Universitas Muhammadiyah Pringsewu \\ Email : naliakunang@gmail.com
}




\begin{tabular}{ccc}
\hline Pekerjaan & Jumlah & Persentase \\
\hline PNS & 1 & 2,4 \\
Wiraswasta & 4 & 9,5 \\
Pegawai Swasta & 10 & 23,8 \\
Petani Buruh & 2 & 4,8 \\
IRT & 25 & 59,5 \\
\hline Jumlah & 42 & 100 \\
\hline
\end{tabular}

Berdasarkan tabel 4.4 diketahui bahwa responden dengan pekerjaan PNS sebanyak 1 responden $(2,4 \%)$, responden dengan pekerjaan wiraswasta sebanyak 4 responden $(9,5 \%)$, responden dengan pekerjaan pegawai swasta sebanyak 10 responden $(23,8 \%)$, responden dengan pekerjaan Petani/buruh sebanyak 2 responden dan responden dengan status IRT sebanyak 25 responden (59,5\%).

Tabel 4.5 Distribusi frekuensi responden berdasarkan di BPM Selva Tiara Kec. Bulok Kab. Tanggamus Tahun 2019

\begin{tabular}{ccc}
\hline Lama Pemakain KB & Jumlah kasus & Presentase $(\%)$ \\
\hline 1-3 Tahun & 10 & 23,8 \\
3-4 Tahun & 15 & 35,7 \\
>4 Tahun & 17 & 40,5 \\
\hline Jumlah & 42 & 100 \\
\hline
\end{tabular}

Berdasarkan tabel 4.5 diketahui bahwa responden dengan lama pemakaian KB 1-3 Tahun sebanyak 10 responden $(23,8 \%)$, responden dengan lama pemakaian 3-4 Tahun sebanyak 15 responden (35,7\%) dan responden dengan lama pemakaian >4 Tahun yaitu sebanyak 17 responden $(40,5 \%)$.

Tabel 4.6 Distribusi Responden berdasarkan peningkatan berat badan di BPM Selva Tiara Kec. Bulok Kab. Tanggamus Tahun 2019

\begin{tabular}{ccc}
\hline Peningkatan Berat Badan & Jumlah kasus & Presentase (\%) \\
\hline Turun & 5 & 11,9 \\
Tetap & 6 & 14,3 \\
Naik & 31 & 73,8 \\
\hline Jumlah & 42 & 100 \\
\hline
\end{tabular}

Berdasarkan tabel 4.6 terlihat bahwa sebagian besar responden di BPM Selva Tiara, A. Md. Keb. mengalami peningkatan badan yaitu sebanyak 31 responden $(73,8 \%)$.

\section{Analisa Bivariat}

\section{*Corresponding Author :}

Analia Kunang

Program Studi D-III Kebidanan, Fakultas Kesehatan

Universitas Muhammadiyah Pringsewu

Email : naliakunang@gmail.com
Tabel 4.7 Hubungan lama pemakaian KB suntik 3 bulan Depo Medrosik Progesteron Asetat (DMPA) dengan peningkatan berat badan di BPM Selva Tiara Kec. Bulok Kab. Tanggamus Tahun 2019

\begin{tabular}{|c|c|c|c|c|c|c|c|c|c|}
\hline \multirow{3}{*}{$\begin{array}{c}\text { Lama } \\
\text { Pemakaian } \\
\text { KB }\end{array}$} & \multicolumn{6}{|c|}{ Peningkatan Berat Badan } & \multirow{2}{*}{\multicolumn{2}{|c|}{ Total }} & \multirow{3}{*}{$\begin{array}{c}P \\
\text { Value }\end{array}$} \\
\hline & \multicolumn{2}{|c|}{ Turun } & \multicolumn{2}{|c|}{ Tetap } & \multicolumn{2}{|c|}{ Naik } & & & \\
\hline & $\mathbf{N}$ & $\%$ & $\mathrm{~N}$ & $\%$ & $\mathrm{~N}$ & $\%$ & $\mathrm{~N}$ & $\%$ & \\
\hline 1-3 Tahun & 3 & 30,0 & 4 & 40,0 & 3 & 30,0 & 10 & 100 & 0,011 \\
\hline 3-4 Tahun & 1 & 6,7 & 1 & 6,7 & 13 & 86,7 & 15 & 100 & \\
\hline$>4$ Tahun & 1 & 5,9 & 1 & 5,9 & 15 & 88,2 & 17 & 100 & \\
\hline Total & 5 & 11,9 & 6 & 14,3 & 31 & 73,8 & 42 & 100 & \\
\hline
\end{tabular}

Berdasarkan tabel 4.7 diketahui responden dengan lama pemakaian KB 1-3 Tahun yang mengalami penurunan berat badan sebanyak 4 responden $(40,4 \%)$, responden dengan lama pemakaian KB 3-4 Tahun yang mengalami peningkatan berat badan sebanyak 13 responden $(86,7 \%)$ dan responden dengan lama pemakaian $\mathrm{KB}>4$ Tahun yang mengalami peningkatan berat badan sebannyak 15 responden $(88,2 \%)$.

Berdasarkan hasil uji statistik diketahui bahwa $p$-value yaitu $0.011<0,05$ ( $p$-value < $0,05)$, sehingga Ho ditolak. Hal ini menunjukan bahwa terdapat hubungan antara lama pemakaian KB suntik 3 bulan Depo Medrosik Progesteron Asetat (DMPA) dengan peningkatan berat badan di BPM Selva Tiara Kec Bulok Kab. Tanggamus Tahun 2019.

\section{Pembahasan Analisa Univariat}

a. Usia

Analisa univariat variabel usia dalam penelitian ini menunjukan bahwa diketahui bahwa sebagian besar responden di BPM Selva Tiara, A. Md. Keb. berusia 22-35 tahun yaitu sebanyak 30 responden $(71,4 \%)$.

b. Jenis Kelamin

Analisa univariat variabel jenis kelamin dalam penelitian ini menunjukan bahwa jenis kelamin seluruh responden di BPM 
Selva Tiara, A. Md. Keb. adalah perempuan yaitu sebanyak 42 responden (100\%).

\section{c. Pendidikan}

Analisa univariat variabel pendidikan dalam penelitian ini menunjukan bahwa sebagian besar responden di BPM Selva Tiara, A. Md. Keb. berpendidikan SMA yaitu sebanyak 29 responden $(69,0 \%)$.

d. Pekerjaan

Analisa univariat variabel pekerjaan dalam penelitian ini menunjukan bahwa bahwa responden di BPM Selva Tiara, A. Md. Keb. memiliki status sebagai IRT yaitu sebanyak 25 responden $(59,5 \%)$.

e. Penggunaan KB Hormonal

Analisa univariat variabel penggunaan KB hormonal dalam penelitian ini menunjukan bahwa sebagian besar responden di BPM Selva Tiara, A. Md. Keb. menggunakan KB dengan lama penggunaan $>4$ Tahun yaitu sebanyak 17 responden (40,5\%).

f. Peningkatan Berat Badan

Analisa univariat variabel peningkatan berat badan dalam penelitian ini terlihat bahwa sebagian besar responden di BPM Selva Tiara, A. Md. Keb. mengalami peningkatan badan yaitu sebanyak 31 responden $(73,8 \%)$.

\section{Analisa Bivariat}

Hubungan penggunaan kontrasepsi

Hormonal 3 Bulan DMPA dengan

Peningkatan Berat Badan.

Berdasarkan hasil uji statistik diketahui bahwa terdapat hubungan antara lama pemakaian KB suntik 3 bulan Depo Medrosik Progesteron Asetat (DMPA) dengan peningkatan berat badan di BPM Selva Tiara Kec Bulok Kab. Tanggamus Tahun 2019 dengan $p$-value 0.011 .

Kontrasepsi hormonal pada umumnya menggunakan hormon estrogen dan progesteron dalam terapinya. Penggunan hormon estrogen dan progesteron akan menstimulus terjadi peningkatan jumlah hormon progesteron dan estrogen didalam tubuh dengan efek androgeniknya. Hormon progesteron pada dasarnya memiliki fungsi dalam mempengaruhi nafsu makan, kelebihan hormon progesteron akan merangsang pusat pengendalian nafsu makan di hypothalamus yang menyebabkan akseptor makan lebih banyak dari pada basanya, sehingga nafsu makan akan bertambah dan berakibat makan lebih banyak yang akhirnya menyebabkan peningkatan berat badan. (Guyton \& Hartanto, dalam Darmawati \& Fitri, 2012).

Kenaikan berat badan juga disebabkan karena peningkatan kadar hormone progesterone yang mempermudah terjadinya penambahan gula dan karbohidrat menjadi lemak, sehingga lemak banyak yang bertumpuk dibawah kulit (Hartanto dalam Irawati, 2017), Selain itu progesteron mempermudah proses perubahan karbohidrat menjadi Triasilgliserol yang hanya dapat dipecah tubuh dengan aktifitas fisik berat (Murray, 2009).

Menurut pendapat peneliti peningkatan berat badan dapat dihubungkan dengan kandungan pada DMPA yaitu hormon progesteron, yang dapat merangsang pusat pengendalian nafsu makan di hipotalamus sehingga menyebabkan terjadinya peningkatan nafsu makan. Perubahan berat badan dapat disebabkan oleh efek samping penggunaan kontrasepsi suntik karena pengaruh hormon progesteron yang mempermudah perubahan karbohidrat dan gula menjadi lemak, sehingga lemak di bawah kulit bertambah.

\section{KESIMPULAN}

Melihat hasil penelitian dan pembahasan penelitian yang berjudul "Hubungan lama pemakaian KB suntik 3 bulan Depo Medrosik Progesteron Asetat (DMPA)

\section{*Corresponding Author :}

Analia Kunang

Program Studi D-III Kebidanan, Fakultas Kesehatan

Universitas Muhammadiyah Pringsewu

Email : naliakunang@gmail.com 
dengan peningkatan berat badan di BPM Selva Tiara Kec Bulok Kab. Tanggamus Tahun 2019" maka dapat disimpulkan :

1. Distribusi frekuensi responden berdasarkan usia diketahui bahwa sebagian besar responden di BPM Selva Tiara, A. Md. Keb. berusia 22-35 responden atau sebanyak $(71,4 \%)$.

2. Distribusi frekuensi responden berdasarkan lama penggunaan KB diketahui bahwa bahwa sebagian besar responden di BPM Selva Tiara, A. Md. Keb. menggunakan KB dengan lama penggunaan $>4$ Tahun yaitu sebanyak 17 responden $(40,5 \%)$.

3. Distribusi frekuensi responden berdasarkan peningkatan berat badan diketahui bahwa sebagian besar responden di BPM Selva Tiara, A. Md. Keb. mengalami peningkatan badan yaitu sebanyak 31 responden $(73,8 \%)$.

4. Ada hubungan antara lama pemakaian KB suntik 3 bulan Depo Medrosik Progesteron Asetat (DMPA) dengan peningkatan berat badan di BPM Selva Tiara Kec Bulok Kab. Tanggamus Tahun 2019 dengan $p$-value sebesar 0.011 .

\section{DAFTAR PUSTAKA}

Arikunto, S. 2009. Prosedur Penelitian Suatu

Pendekatan Praktik. Edisi Revisi 6. Jakarta : Rineka Cipta.

Badan Penelitian dan Pengembangan Kesehatan Kementrian Kesehatan

$\mathrm{RI}$,

Riset Kesehatan Dasar, 2013.

Darmawati \& Z. Fitri. 2015. Hubungan penggunaan kontrasepsi hormonal dengan kenaikan berat badan pada akseptor kontrasepsi hormonal di desa Batoh.

Erawati D. (2015). Hubungan Lama

Pemakaian Kontrasepsi Suntik

\section{*Corresponding Author :}

Analia Kunang

Program Studi D-III Kebidanan, Fakultas Kesehatan

Universitas Muhammadiyah Pringsewu

Email : naliakunang@gmail.com dengan Peningkatan Berat Badan pada Akseptor Suntik Depo Medroksi Progesteron Asetat. Skripsi, di Bidan Praktik Mandiri (BPM) Sugiyati Kajoran Magelang (Diakses tanggal 04 Agustus 2017)

Fitiraningsih, H. 2015. Hubungan penggunaan kontrasepsi DMPA dengan kejadian peningkatan berat badan dan upaya penanganannya.

Hardjito, K (2010). Analisis perbedaan berat

badan sebelum dam sesudah menggunakan alat kontrasepsi implant lebih dari lima tahun.

Hartanto. 2014. KB dan Kontrasepsi. Jakarta: Sinar Harapan.

Humayrah W. 2009. Faktor gaya hidup dan hubungannya dalam resiko kegemukan orang dewasa di

Provinsi

Sulawesi Utara, DKI Jakarta dan Gorontalo. [Skripsi] Bogor: Institut Pertanian Bogor.

Irawati, A. 2017. Validitas Lingkar Lengan Atas Mendeteksi Risiko

Kekurangan

Energi Kronis pada Wanita Indonesia. Jurnal Kesehatan Masyarakat Nasional Volume 7 Nomor 2. ISSN : 1907 - 7505.

Irianto, K. 2015. Anatomi dan Fisiologi untuk Mahasiswa. Bandung: Alfabeta

Lesmana, Vera, Irianto, Gunawan, Amirus Khaidar, 2012. Jurnal IImiah Hubungan penggunaan Kontrasepsi KB dengan Gangguan siklus Haid, Tanggamus.

Majalah Ilmiah Sultan Agung vol. 126, 2012. Mamarimbing, S., Rattu, J.A.M., Tumurang, M.N. 2016. Faktor-faktor yang Berhubungan dengan Kejadian Obesitas pada Wanita Usia Produktif di Wilayah Kerja Puskesmas Tinoor Tomohon Utara. 
Community Health. 1 (4): 140-152.

Manuaba, I. A. C. 2010. Pengantar Kuliah Obstetri.. Jakarta: EGC.

Mulyani, Nina siti, Rinawati, Mega, 2013, Keluarga Berencana dan Alat Kontrasepsi. Yogyakarta, Nuha Medika.

Murray, R. K. 2009. Biokimia harper (27 ed.). Jakarta: Buku Kedokteran EGC.

Notoatmojo, S. 2010. Metedelogi Penelitian Kesehatan. Jakarta: RinekaCipta.

Nursalam, 2013. Konsep dan penerapan metedologi penelitian ilmu keperawatan. Jakarta: Salemba Medika.

Octasari, Febria, Sarumpaet, SoriMuda, Yusad, Yusniwarti, 2014. Hubungan Jenis Lama penggunaan Alat Kontrasepsi Hormonal Terhadap Gangguan Menstruasi pada Ibu PUS, Kota Medan.

Pratiwi, D., Syahredi \& Erkadius. 2014. Jurnal Kesehatan Andalas, Hubungan antara penggunaan kontrasepsi hormonal suntik DMPA dengan peningkatan $B B$ dipuskesmas Lapai Kota Padang.

Profil Kesehatan Provinsi Lampung Tahun
2016.

Pusat Data dan Informasi Kementrian Kesehatan RI, Situasi dan Anlisis Keluarga Berencana, 2014, Jakarta Selatan.

Setyaningrum, Agustina Catur. 2008. Jurnal IImiah Hubungan Lama Pemakaian

Mestruasi, DMPA dengan Gangguan Purwodadi.

Suli, Lale AngginTirtha. 2018. Hubungan Penggunaan Kontrasepsi Suntik DMPA dengan kejadian peningkatan $B B$ di BPS IstriUtami, Yogyakarta.

Sulistyawati, A. 2013. Pelayanan Keluarga Berencana. Jakarta: Salemba.

Susilowati, E. 2012. Majalah IImiah Sultan Agung Vol L. No, 126. Semarang.

UU Republik Indonesia No. 36 Tahun 2009 Tentang Kesehatan.

Vista Bunda. (2013). Manfaat Olahraga bagi Kesehatan Mental.

http://vistabunda.com/kesehatan/manfaatola hraga- bagi-kesehatan-mental/. Diakses tanggal 17Desember 2019. Jam 22.30

Widiantini, W. Z. T. Aktifitas Fisik, Stres dan Obesitas Pada Pegawai Negeri Sipil. J Kesehat Masy Nas. 2014;8(7):329336.

\author{
*Corresponding Author : \\ Analia Kunang \\ Program Studi D-III Kebidanan, Fakultas Kesehatan \\ Universitas Muhammadiyah Pringsewu \\ Email : naliakunang@gmail.com
}

